\title{
Regionalism in Competition: EU Experience and its Theoretical Implications for Asian Integration
}

\author{
Hungdah Su
}

Published online: 10 November 2012

(C) CEEUN 2012

\begin{abstract}
In parallel of rise of Asia and particularly the PRC, different approaches to Asian regionalism have emerged on international scene, which, according to the author's detailed analysis, can be divided into four approaches. They were respectively advocated by the US, Japan, the PRC and ASEAN and have been competing with each other in their quest for leadership in Asian integration. In order to measure their potential development and impact on Asian regionalism, the author took reference of the similar competition in the European integration between 1950 and 1974 and its theoretical explanation. The author then formulated a framework of analysis composed of four indicators in the region: power structure, cooperation of transnational elite, potential spillover of the original integrated sector and the institutional building. Having evaluated the four approaches to Asian regionalism with help of these indicators, the author concluded that the US-led Trans-Pacific regionalism still dominates Asian integration for the US is far more powerful than any other individual powers or any coalitions in the region. It could easily mobilize those pro-US elite throughout Asia. The pathfinder and later TPP in APEC could serve as an integrated sector potentially producing spillover in related fields. However, American approach's Achilles' Heel is its failure to build up strong institutions owing to Washington's passive and reluctant attitude towards Asian regionalism. If Washington refuses to adapt itself to the fast evolving Asian regionalism, it could leave place to the PRC or even ASEAN in a long run as China's economy is fast developing and its political influence is rapidly rising and ASEAN is accelerating construction of its own communities.
\end{abstract}

Keywords Asian integration - European Union - Trans-Pacific Partnership · Integration Theory

\footnotetext{
H. Su $(\bowtie)$

Department of Political Science, National Taiwan University, 21, Xu Zhou Road, Taipei, Taiwan, ROC

e-mail: hdsu@sinica.edu.tw
} 


\section{Introduction}

In spite of current Euro crisis, the entry into effect of Lisbon has brought to a victorious end the European Union (EU) Constitution-Building movement initiated with the Laeken Declaration in 2001. In parallel with the fall and rise of the EU constitutionbuilding process between 2005 and 2010, Asian integration-or more exactly, integrations-was also fast evolving, though in a far less impressive way than European integration. During the first decade of the new millennium, different strategies for regional integration were emerging in Asia and competition among these has become more and fiercer with the accelerating rise of the PRC since the financial tsunami and the decision of the US under Obama's leadership to adopt a more active policy in Asia. With the aim of comparing different strategies for Asian integration and evaluating their political implication for regional politics, I will first review four competing approaches to Asian integration before analyzing the theoretical debate over the similar competition of regionalism in the EU history between 1945 and 1974. Based upon this empirical comparison and theoretical exploration, I will compare and evaluate the different approaches to Asian regionalism and their implication for the future of Asia before drawing some conclusions.

\section{Asian Regionalism in Competition}

For economists, regionalism may be indicative of those "institutional arrangements designed to facilitate the free flow of goods and services and to coordinate foreign economic policies between countries in the same geographic region". ${ }^{1}$ For political scientists, it may be any "vertical and horizontal institutionalization" of regional cooperation, which might later develop into a new regional polity. As no integration project in Asia aims to build a supranational or federal polity, in this paper, I prefer to define regionalism as "any institutional arrangements based upon intergovernmental agreements with the aim of facilitating the creation of a free trade zone, a single market, the coordination of policies and construction of common institutions between signatory states or economic polities".

The debate over Asian integration appeared on international scene in the mid1960s. Evidently inspired by European integration, some industrialists and political leaders in Japan began advocating economic cooperation among those pro-American countries in Asia and/or in the Pacific. The creation of the Pacific Economic Cooperation Council (PECC) and the Pacific Basin Economic Council (PBEC) marked success but limits of the Japan-initiated integration projects. Handicapped by its militarist past in WWII, its thirst to be integrated into the West since Meiji reform and lack of American full support, Japan failed to lead Asian integration even when its economic power was ceaselessly rising (Endo 2002). Between mid-1980s and mid1990s, Australia came to the forefront of Asia-Pacific integration, generally supported by the US. While the creation of Asia Pacific Economic Cooperation (APEC) was a typical Australian project for regional integration, the holding of APEC summit was expression of American firm resolution to lead and/or contain integration in the

\footnotetext{
1 "Economic regionalism", Encyclopedia Britannica.
} 
region. In the aftermath of Asian financial crisis in 1997, Japan proposed to establish an Asian Monetary Fund (AMF) in the framework of Asian Development Bank (ADB) as a regional monetary mechanism. As regards the Association of South East Asian Nations (ASEAN), it decided to establish its free trade zone and enlarged its membership in 1990s. Until the end of 1990s, the APEC under the dual leadership of US and Australia, the ADB under the dual leadership of US and Japan, and the ASEAN competed to take leadership of Asian integration. Since the turn of millennium, the rise of China has been accelerating and, at the same time, restructuring integration in Asia (Economy 2005).

\section{America-led Trans-Pacific Regionalism}

Driven by so-called open regionalism, the APEC aims to create a loosely organized free trade zone for industrial goods plus a political forum. Not until the 2009 Summit in Singapore did APEC leaders agree to appoint an executive director to a 3 -year term, bringing an end to a 20 -year rotational system. ${ }^{2}$ The trans-Pacific nature of the APEC serves well the American interests, for it can contain and mitigate any Asian integration without the US (Green 2007; Elek 1998). Vis-à-vis the rising regionalism in Asia in the mid-1990s and the slow progress toward the Bogor Goal in APEC, the US and Australia firstly initiated a 'pathfinder strategy' within the APEC which permitted sub-integration among member states in limited fields. With this project of sub-integration in mind, the US and Australia intended to consolidate the pro-free trade and pro-US group as a dominant bloc inside of the APEC (Su 2007). In late 2008 and early 2009, the US and Australia renewed their strategy by announcing that they would begin negotiations to join the Trans-Pacific Partnership (TPP). Originally signed by Singapore, New Zealand, Chile and Brunei in 2005, the TPP aimed to create a Bogor plus FTA (so-called high quality FTA) among them. According to the agreement establishing TPP, signatory states should eliminate nearly all trade tariffs in goods and service before 2015, establish many common rules aimed to invalidate those non-tariff barriers, and open its governmental procurement market. Following the American and Australian decisions, Peru, Malaysia and Vietnam also joined the negotiations. This TPP group would form another pro-American group inside the APEC. As a result, the pathfinder and TPP have constituted two pillars inside the APEC that would permit the US and, to a lesser degree, Australia not only to join but also lead the Asian integration. As State Secretary Hilary Clinton said at ASEAN Regional Forum in July 2009, with these initiatives, US intended to promote its export to Asia-Pacific, to maintain its dominance in the region and to contain the rising China (Du 2011).

\section{Japan-Preferred Integration Inside the ADB Framework}

As for Japan, its most ambitious projects for Asian integration were presented respectively in the aftermath of Asian financial crisis of 1997 (Webber 2001), and

\footnotetext{
${ }^{2}$ The first executive director is Muhamad Noor Yacob, the former Malaysian permanent delegate to the WTO in Geneva. APEC official website. http://www.apec.org. Retrieved 25 Nov 2009.
} 
global financial tsunami in 2008. In 1997, Tokyo proposed the establishment of an "Asian Monetary Fund" (AMF) among member states of ADB, which might pave the way to further intra-Asian economic and monetary cooperation. Inside this integration, Japan was expected to play a leading role owing to its economic and financial strength then, its prominent status at ADB and its special relationship with the US in Asia (Green 2002). Nearly a decade later, Japanese Prime Minister Yukio Hatoyama publicly advocated in September 2009 that Japan should consider constituting, jointly with the PRC and South Korea, an Asian community. Hatoyama asserted that such a project could benefit Japan as it would counter-balance its inappropriate and disproportionate dependence upon the US. According to his Foreign Minister Okada, this envisaged community would even include all member states of ASEAN, India, Australia, and New Zealand. Near the same time, Haruhiko Kuroda, the Japanese President of the Asian Development Bank proposed debating the creation of an Asian common currency to help Asian countries better safeguard themselves in the face of international financial crises. Unfortunately, all of these Japanese proposals ended with failure. Owing to American opposition, Japan withdrew its support of the AMF and ended up signing an agreement in Chiang Mai (Thailand) in May 2000 with the PRC, South Korea and the ASEAN which established a network of bilateral swap agreements worth US $\$ 80$ billion (Kohlscheen and Taylor 2008). Ten years later, Hotayama's proposal ended with signature of an agreement of goodwill between Beijing, Soeul and Tokyo in October 2009. Three countries agreed to develop "East Asian community based on principles of openness, transparency, inclusiveness as a long term goal" without, however, mentioning any concrete roadmaps and timetables. Japan seemed to be trapped in a dilemma similar to that of Great Britain with regards to regional integration. On the one hand, its insular nature and mercantilism prevented Japan from opening its domestic market, and accordingly inhibited advocacy of strong regionalism in Asia (Miller 2004; Yung Chul Park 2002). For example, Japan was even absent from the sub-integration group based upon pathfinder within the APEC, initiated by US and Australia. On the other hand, constantly awaiting American endorsement to pursue its policy of Asian integration, Japan was denied an independent integration policy.

ASEAN-Favored Balanced Tripartite Integration

After the end of the Cold War, the ASEAN countries made effort to reinforce their common identity as an independent polity, and simultaneously promote Asian integration of which ASEAN must play the core role. In the past two decades, ASEAN was ceaselessly deepening its own integration by signing an agreement, in 1992, establishing a free trade zone within 15 years. The member states of ASEAN also signed the Southeast Asian Nuclear-Weapon-Free Zone Treaty in 1995, which banned all nuclear weapons in the region. While the free trade zone would create economic solidarity, the non-nuclear zone will give ASEAN a political identity in the region. The integration of ASEAN entered into a new phase when its summit in Kuala Lumpur in December 2005 decided to establish an "Eminent Persons Group" to study the feasibility of drafting an ASEAN Charter. While this group could be 
inspired by the wise men model in the European integration and the idea of drafting a Charter could refer to the proposal establishing the abortive European Constitutional Treaty, the ASEAN Charter and the way toward its adoption was fundamentally an intergovernmental action. In 2008, the ASEAN Charter formally came into effect, with the aim of creating political, economic and cultural communities no later than 2015. In parallel of its deepening, ASEAN was ceaselessly extending its membership to the whole South East Asia and created a regional body composed of ten sovereign states and 600 millions people with an annual GDP of 3,000 billion US\$ in 2010.

The successful deepening and widening of ASEAN permitted some of its leaders, particularly the former Malaysian Prime Minister Mahathir, to advocate the organization of a larger regional unit that would include the ASEAN and neighboring countries in the aftermath of Asian financial crisis. This was the beginning of the 'ASEAN plus' process of which ASEAN must be at the center.

The ASEAN-led integration aimed to achieve three objectives: strengthen its internal balance, counter-balance the West-led Pacific integration, and contain the rising Asian powers, in particular, China. Before all, by deepening and widening their own integration, ASEAN countries intended to maintain their internal balance. Similar to other regional integration, ASEAN was interpreted as the containing framework imposed by the weaker part like Malaysia and Singapore upon the potentially hegemonic countries such as Indonesia and Vietnam. Following this logic, ASEAN plus could be regarded as a contribution to reinforcement of its internal balance as those regional hegemonic countries would be now constraint by outside powers such as Japan and China. ASEAN plus would at the same time strengthen ASEAN as a whole and counterbalance the trans-Pacific integration initiated by the Western powers. However, if ASEAN Plus constituted itself as a final objective, ASEAN countries could risk being dominated by its Northern neighbors such as Japan and China. In order to avoid this dilemma, ASEAN leaders intended to enlarge the ASEAN Plus process to include India and those non-Asian powers. In 2009, ASEAN countries signed an FTA, respectively, with Australia and New Zealand. Given its own interests, this ASEAN Plus process should ideally lead to an Asian regional entity composed of the ASEAN, its powerful Asian neighbors, and Western powers such as Australia and/or the US. The East Asian Summit, held annually since 2005, represented the ideal of this ASEAN's regionalism, with East Asia represented by China and Japan, South Asia with India in the lead, and Western powers represented by Australian and now US. The participation of each outside power was balanced by the others and ASEAN became consequently the balancing and coordinating player in it.

\section{China-planned Two Concentric Circles of Integration}

Competition for leadership of the process of Asian integration entered a new era in 2002-2003 as the PRC and the ASEAN signed an agreement to establish a free trade zone in 2010 (Economy 2005), and Chinese leaders made it clear for the first time that the Shanghai Cooperation Organization (SCO) should aim for creation of a Free Trade Area in the long run. These seemingly irrelevant events could represent the 
grand strategy of China in the 21st century with the aim of constituting two circles of integration, in which China would be at the center.

Chinese approaches to integration differ in the processes of SCO and ASEAN plus. In term of structure, SCO has established a hierarchical structure, on the top of which are the Council of Head of States and the Council of Prime Ministers as all member states have adopted semi-presidentalism. As regards the ASEAN plus process, it is more a group of treaties than a strictly defined organization. In the Framework Agreement between ASEAN and PRC, no institutions other than the Trade Negotiations Committee (TNC) were set up. Though it holds now a summit, sixteen regular ministerial meetings, 23 meetings of senior officials and seventeen technical cooperation workshops per year, its institutionalization is in general affiliated to the ASEAN structures and its summits often reiterated the driving force of ASEAN in the process. SCO and ASEAN Plus also started their integration in different fields. Even before its formal inauguration, member states agreed to establish the SCO in order to maintain the security in the region, which later developed into the confidence-building measures (CBM), anti-terrorist cooperation, intelligence sharing, and even some small-scaled joint military exercises. Though SCO declared categorically that it was not an alliance directed against any other states or organizations, it was regarded in general as the most important nonWestern grouping, indirectly challenging or even opposing to those values to which EU and US adhered. In the name of anti-terrorism or counter extremism, member states of SCO supported each other's suppression of bordering minorities. At its summits, SCO leaders welcomed Iranian President Admadirejad and tolerated his anti-US allocution.

Contrary to SCO, ASEAN Plus was deliberately designed as an apolitical building in the region. All cooperation in ASEAN Plus focuses on trade-related issues, including transport, tourism, public health, industry, investment, culture and energy. These two China-planned integration movements also differ in power structures and Chinese strategic designs. The PRC explicitly cooperated with Russia to constitute a dual leadership inside the SCO. In other word, the SCO was created as a fruit of the Sino-Russian détente and entente in the post-Cold War era and particularly after the signature of a series of treaties setting the demarcation of disputed 4,000 km border between the two giant countries. The member states of SCO signed its Charter and formally established this organization one year after the PRC and Russia had signed the Treaty of Good Neighborhood and Friend Cooperation in July 2001. The official languages of SCO are Chinese and Russian. On the contrary, Chinese leaders never consulted any other powers in the region, for example Japan, throughout its initiation and implementation of ASEAN Plus process. Though leaving the leading role of ASEAN Plus to ASEAN and some South Eastern leaders, China is evidently the most powerful member in this process and the power gap between China and other seems to be widened in the coming years. For China, this process is reinforced by its agreement with Taiwan that created the Economic Cooperation Framework Agreement (ECFA).

These two circles of integration, respectively, based upon SCO and ASEAN Plus might constitute the most important regionalism of China in the 21 st century. "[T]he ASEAN-China agreement cannot be viewed purely from the economic 
benefits that may result from the agreement", concluded two ASEAN experts, "but also from geopolitical powerplay perspectives, particular between China and Japan and even between China and the USA" (Chia and Sussangkarn 2006). With the ASEAN plus one framework and, to a lesser degree, the ECFA with Taiwan, the PRC might intend to establish "a production network with China at the centre"(Men 2007), or even an East Asian trade group with the RMB serving as a hard currency in the long run. Given China's fast economic expansion, the geopolitics of Asian integration were reshaped between the late 1990s and early 21 st century in favor of the PRC (Boisseau du Rocher 2006).

\section{Theoretical Debate over the Competing European Regionalism Between 1945 and 1974}

In order to evaluate the future development of these competing approaches to Asian integration, it is necessary to find out the key factors that shape regionalism in world politics. As the mainstream integration theories were developed on the basis of empirical studies of European integration since 1950, it will be relevant to analyze the theoretical debate over the similar competing regionalism in Europe between 1950 and 1974.

Three Approaches to European Regionalism

During this period, three approaches to regionalism competed to dominate the process of Europe-building: British, Gaullist and Monnet's regionalism. Churchill advocated publicly the creation of a United States of Europe in his famous speech in Zurich in 1947 and presided over the Hague Congress in 1948, leading to the establishment of the Council of Europe (Harryvan and van der Harst 1997). However, Europe-building was never a core value of British foreign policy after WWII. After the war, Churchill designed a three-circled strategy to guide British foreign policy and the British governments put emphasis upon the maintenance of its empire and later Commonwealth as well as its special relationship with the US. Europe-building, or European cooperation, was the last circle in Churchill's strategic design, and not a source of British influence or power in the world, but a bulwark against war or the threat of a dominant power rising again on the continent. Accordingly, the British governments developed its European strategy in late 1940s and early 1950s with the aim of constituting a loose, cooperative arrangement in Western Europe that would permit Great Britain to influence and participate freely in what it deemed the necessary fields, where the UK enjoyed a dominant position, and in which this cooperation would contribute to its bargaining with the US. British regionalism was therefore characterized by loose intergovernmental cooperation, a pro-status quo orientation, support for ever-enlarging membership and passivism as a counter-project to the federalists' call for an ever-closer Europe (George 1992).

At the other extreme was the Monnet's regionalism. Honored as the Father of Europe and the first European citizen, Jean Monnet developed a long-term strategy for European integration in the mid-1950s, which was generally supported by many 
pro-integration movements in Europe ( $\mathrm{Su} 2009$ ). Advocating economic integration sector-by-sector, Monnet supposed that integration should extend to the political field when the timing allowed it. According to Monnet, timing not planning was the vital factor for successful integration. That was why he dared to present the Pleven plan to create a European army under the European Defense Community (EDC) in early 1950s, supported the Fouchet Plan in 1960, advocated establishment of a 'European District' in Brussels in the late 1960s and proposed to Giscard d'Estang the establishment of a European Government composed of the heads of states and governments in 1972. Monnet's regionalism was pursuing ceaselessly for the Federation of Europe. As regards Europe's role in world politics, Monnet insisted that a unified or unifying Europe must cooperate with the US, both of which constituting a solid alliance in all fields. In fields where Europe was still far from unified, Europeans should accept American leadership, whereas in those fields where European countries had formed an integrated community, Europe and the US should formulate a dual leadership arrangement. Monnet's regionalism was characterized by a federalist vision, constant activate movement, pro-American attitude, a flexible strategy but a clear and fixed long-term objective.

In contrast to Monnet's method, the Gaullist regionalism insisted that all transnational cooperation must begin with creation of a political framework (Bloes 1970). Also diverging from Churchill's strategy, the Gaullist way aimed to create deeper, more structured European cooperation in all fields. Through such cooperative steps, all member states maintained sovereignty but were able to assist each other in the global political sphere. As a result, Europe would grow to reinforce existent European nations internally and externally, not vice versa. The most powerful of these nations, certainly France for the Gaullists, would become the natural leader of this inter-state group. This group, kleiner Europa, would constitute the core force in a grosser Europa including the ex-Soviet Union (Soutou 1996). For this reason, Kissinger compared De Gaulle's Europe to Bismarck's Germany, as both were envisioned as being dominated by their most powerful member. The Gaullist regionalism was therefore characterized by intransigent intergovernmentalism, an emphasis on politics, a vision of a Europe of states exhibiting solidarity, and yet independent of non-European superpowers in world politics.

\section{European Regionalism in Competition}

Until Schuman presented his historical plan on 9 May 1950, British strategy prevailed over the other two as the leading vision of European integration. As the only European nation to emerge as truly victorious from WWII and, more crucially, the only power in Europe wholly exempt from collaboration in the Nazi genocide, Great Britain was the ideal nation, and Churchill the ideal statesman, to advocate European integration in the aftermath of the war. The Organization of European Economic Cooperation (OEEC) supplied the Great Britain with a platform to coordinate economic cooperation among European countries while the Western Union-supported later by the Atlantic Alliance Treaty-gave the Great Britain a leading role with regards to military cooperation in Europe. Based upon this ecomilitary cooperation structure, GB and Churchill supported The Hague Congress 
and worked hard to put into place the Council of Europe in 1949 (Gerbet 1983). The Council of Europe seemed to be a miniature version of the reformed League of Nations and an institutionalized European concert of powers, based purely upon intergovernmental cooperation. The Committee of Ministers constituted the highest decision-making organ, where unanimity and consensus were installed as voting rule. An assembly composed of delegates from national parliaments was organized as a consultative body. Though a court and a commission were inaugurated to protect human rights in Europe, until 1998, no direct jurisdiction over member states was established.

Though British regionalism was challenged by Monnet's regionalism after Schuman Plan was published and the European Coal and Steel Community (ECSC) was created in 1952, it was not defeated. Between 1950 and 1955, these two strategies came into competition with each other. The Pleven Plan creating the EDC and a European army represented a great leap forward of Monnet's regionalism, which, however, ended in disaster. Monnet was forced to resign the presidency of High Authority of ECSC and terms such as 'federalism' or 'supranational' became taboo among mainstream political forces in Europe (Kohnstamm 1984). Two months after French veto of the EDC, the Western Union was restructured as West European Union (WEU) to incorporate the rearmed West Germany, bringing an end to conflicts originating over German rearmament. The success of the WEU and failure of the EDC in 1954 reconfirmed the ascendency of the British strategy in Europe-building in spite of the Schuman Plan and creation of the ECSC (Dumoulin 2000).

This proved to be the peak of the British regionalism in the history of Europebuilding. Since then, Monnet's regionalism shifted focus, taking aim on complete economic integration with the EMU project and beginning political cooperation as the first steps toward ultimate political unification. Eight months later, the Messina conference was convened by six foreign ministers of the ECSC. Despite having received an invitation, the British government sent a senior official as an observer, implicitly rejecting the proposed community-building project (George 1992). After the ECSC Six had begun negotiating the future Rome Treaties, the British government proposed discussing the creation of a free trade zone among all the member states of the OEEC. British strategy evidently aimed to invalidate the customs union of the CSCE Six with a larger free trade zone, and to put the newly created EEC under the institutional framework of the OEEC. Owing to the French veto and federalists' skepticism, negotiations on a Western European Free Trade Zone were suspended in 1958, leading to creation of the European Economic Community (EEC) Six and European Free Trade Association (EFTA) Seven.

Macmillan's decision to knock on the door of the EEC in 1961 was interpreted as a British surrender to Monnet's regionalism, the dominant strategy between the mid1950s and mid-1960s in Europe-building. Encouraged by the optimism surrounding the Common Market, Monnet's strategy next embraced general economic integration (Lagrange 1980). In 1958, the Rome treaties entered into effect, creating simultaneously the European Economic and Atomic Energy communities. In 1961, the first common policy and market on agriculture was formally instituted. In 1967, administrative institutions of the three existing communities were merged. 
One year later, a customs union between the EEC Six was complete, one and half years earlier than presupposed in the treaties. Although brought into doubt by the empty chair crisis, De Gaulle's détente with the ex-Soviet Union, and French second veto on British accession, Monnet's regionalism was nonetheless revived at The Hague summit in 1969. That summit featured a green light to British admission, an avowal to develop the Economic and Monetary Union, the beginning of plans for direct elections of a European Parliament and revival of political cooperation in world politics.

The Gaullist regionalism appeared to prevail in 1960-1961 when the EEC Six gave different supports to the French Fouchet Project creating the European Political Union (EPU). However, Fouchet Project proved to be a failure as De Gaulle intervened personally to enlarge the developing EPU in order to govern the existing EEC and further develop military cooperation-implying a potential challenge to NATO. In spite of this failure and a series of actions between 1963 and 1969 taken by De Gaulle and interpreted as anti-European, the birth and development of European Political Cooperation (EPC) after 1970 reconfirmed the Gaullist intergovernmental cooperation strategy in Europe-building (Duke 2000). The convention of the first European Summit, in Paris, in 1974, marked the beginning of parallelism of the Gaullist and Monnet's regionalism on Europebuilding, which continues to this day. Though the internal market is still far from a national market-in which taxation and economic policies are unified-the European Union already acts as an integrated economic actor and the first-ranked GDP power on the international scene; its economic clout could even provide a basis for its diplomatic efforts. Even cooperation on justice and police affairs started with a purely intergovernmental structure ended with partial integration into the community pillar. With regards to the Gaullist regionalism, all the intergovernmental cooperation on diplomatic issues continues in the intergovernmental operation mode. All attempts aiming to 'federalize' or 'integrate' this intergovernmental cooperation proved to be failure to the extent that they ended ironically with further consolidated intergovernmental structure. The EDC project in 1952-1954, the debate over the nature of the future Union in 1990-1991, and the constitutionbuilding in 2002-2005 all aimed to 'federalize' or 'integrate' to some degree the then existing Communities or/and Union, and all failed. Intergovernmental cooperation in political issues remains as solid as the Gaullists' regionalism advocated.

\section{Theoretical Debate}

Theoretical debate over European competing regionalism of this period made it clear that each approach put emphasis upon different driving forces in regional integration. Liberal intergovernmentalism (LI) insisted that states remained the key actors in transnational integration. It assumed that all member states were democratic and pluralist, and that the national interest of each state was formulated in the interactions between different domestic interest groups. The national interest thus formulated would provide guidelines to governments during international negotiations. In other words, governments or their negotiators acted as agents of 
domestic interest groups at international levels. The negotiated results would reflect the outcomes of power struggles and compromises between the most influential participating countries. In negotiations over regional integration, the negotiators would have to opt for different institutional building projects, which would themselves indicate the direction of future integration. Moreover, external powers might enjoy a certain influence over regional integration (Moravcsik 1991, 1993, 1995).

Following LI, the development of Europe-building in the past six decades just reflected authentically the reality of power structures within the then European Communities and their member states. As no single European power could dominate this building process, common denominators were agreed to by all in order to satisfy each power, although none was entirely satisfied. More importantly, European regionalism was dependent upon the transnational coalition of most powerful politic-economic groups inside states of Europe. Between 1945 and 1949, the Great Britain was the most powerful state in Europe excluding ex-Soviet Union while the French governments were busy drafting a new constitution to reestablish legitimacy of the Republic. Furthermore, without Germany's firm support, France alone could never challenge British regionalism. Endeavoring to stimulate economic growth and restore social order in the Great Britain, all of its political forces, business communities and labor unions then put emphasis upon the integrity of empire or Commonwealth and its special relationship with the US. British regionalism then became the common denominator among domestic forces, accepted by other European countries. British regionalism was under challenge since 1950 as France and West Germany agreed to work together. More exactly, Monnet's regionalism prevailed since 1950 as it represented the common denominator not only between the EEC Six, but also between their mainstream political parties and a majority of their entrepreneurs. Monnet's regionalism was later challenged by the Gaullist regionalism after the restructuring of political life in France in 1958. However, this Gaullist regionalism must compromise with Monnet's regionalism, still firmly supported by the mainstream political forces and their business leaders in other member states of EEC as well as a majority of French enterprises (Howarth 2001).

In spite of differing forms or interpretations, neofunctionalism emphasized the inner dynamic with spillover on the top in regional integration, to which cooperation among transnational elite in providing leadership was indispensable. Integration in one sector would develop into further integration in another sector in a virtuous and self-reinforcing cycle. This ceaseless virtuous cycling would lead to a point of no return, after which economic integration could be consolidated to the extent that political integration could be undertaken (Hass 1958, 1964, 1975; TranholmMikkelsen 1990; Hoffmann 1982; Paul and Groom 1983). ${ }^{3}$ Emphasizing spillover as an inner dynamic and transnational cooperation among elites on leadership issues, neofunctionalism easily explained the limits of British and Gaullist

\footnotetext{
${ }^{3}$ The uniting of Europe: political, social and economic forces 1950-1957, 2nd edn. Stanford University Press, Stanford, 1968; Regional integration: theory and research. Harvard University Press, Cambridge, 1971
} 
regionalism. The British approach failed to mobilize the passions of the elite in other European countries, and, to be worse, the Gaullist regionalism might awaken nationalism in Europe. The intergovernmental cooperation favored by these two approaches could never produce positive spillover effects as the result of an inner dynamic, without which the cooperation could never constitute a horizontal solidarity. Therefore, a majority of neofunctionalists opted for Monnet's regionalism, deemed available for European integration. For them, the rise and fall of Monnet's regionalist strategy corresponded well to the degree of cooperation among transnational elites and the spillover dynamics associated with planned integration.

Rational choice institutionalism (RI) emphasized the leading force of supranational institutions and their leaders in regional integration, as well as power struggles between supranational leaders and national leaders. Though LI and RI both regarded power struggles among leaders as key factors in European integration, they differed as the latter treated supranational leaders and institutions as actors in these power games, as important as those national leaders (Hall and Taylor 1996). Throughout the construction of the ECSC and the EEC, no one could deny the key role played by Jean Monnet. In the 1960s, Monnet's Action Committee for the United States of Europe succeeded in assembling key statesmen and trade union militants of the EEC Six, which constituted the leading behind the scene force in European integration of that period. The empty chair crisis in 1965 could be interpreted by RI as a defeat of Hallstein - then Commission President and a supranational leader-by De Gaulle, a national (and nationalistic) leader. The Hague Summit was interpreted as a compromise not only between governments of the Six and the Great Britain, but also between these national leaders and those supranational forces with Jean Monnet as a leader and an inspirer.

Sociological institutionalism (SI) emphasized moral forces and cognitive influences in processes of region-building. The moral dimension included values and norms, the former indicating the fundamental objectives of the polity while the latter established a framework for behavior; "of how things should be done and what are the legitimate means to pursue certain ends". The cognitive dimension of regionalism should constitute the reality, connecting individuals to its new social and political order (Laffan 2001). Following this logic, regionalism equipped with more appealing values and norms and more persuasive cognitive influences should prevail over those with ambiguous ones, for the lack of moral and cognitive forces would indicate a failure to integrate, leaving those integrated results to be easily shaken by internal or external challenges (Richard and Haerpfer 1995). British regionalism, therefore, was deemed to be a failure, even at the very beginning, for it lacked a concrete vision and norms and deliberately reduced its cognitive influences. It seemed to prevail in late 1940s only because other approaches to regionalism based upon clearer values and norms and equipped with more powerful cognitive forces had not yet been formulated. On the contrary, Gaullist and Monnet's regionalism was based upon appealing values and norms and was cognitively appealing. The former could provoke national pride in the framework of intergovernmental Europe while the latter gave rise to federalist spirit of all 
Europeans. A Europe unified by following Monnet's regionalism should not only be able to guarantee peace in Europe, but also, jointly with US, act as a defender of peace and humanitarian values worldwide. Such nearly Wilsonian appeals reinforced Monnet's regionalism to the extent that successive waves of enthusiasts working for a federal Europe emerged. The failure of one movement represented not an end, but the birth of another wave. Unlike Monnet's regionalism, the Gaullist regionalism aimed to create a Europe of States. Emphasizing the grandeur of nations and, to a lesser degree, European civilization, it acknowledged the existence of conflicting values in European integration. Promoting the grandeur of Europe as an actor in world politics, the Gaullist regionalism did stimulate the development of unified EU external actions; however, it could also easily provoke patriotism or even nationalism among Europeans, in opposition to European integration. Accordingly, since early 1960s, European integration became competition and compromise between these two approaches to regionalism representing two systems of values, norms and cognition.

Historical institutionalism (HI) emphasized the force of path dependency, which explained "how the set of decisions one faces for any given circumstance is limited by the decisions one has made in the past, even though past circumstances may no longer be relevant." The deductions of HI were based on the bounded rationality: the principle that even great leaders were unable to foresee the long-term consequences of their decisions, and might, ironically, pave the way for that which they would rather avoid through the decisions they adopt (Leibfriend and Pierson 1997; Pierson 1996). In explanations of abovementioned European integration, HI highlighted this ignorance regarding future outcomes. The Gaullist regionalism, for example, which underlined the importance of national leaders of European powers as a key factor, often underestimated the long-term influence of supranational institutions (Garrett and Tsebelis 1996). While De Gaulle spent much of his energy resisting the adoption of a majority vote by the Council of Ministers in Brussels, the European Court of Justice issued two judgments, respectively, in 1963 and 1964 that established the principles of direct effect and primacy in the EU Law. When Thatcher agreed to the Single European Act (SEA) - then thought to be the end of economic integration-she never imagined that, under Jacques Delors' strong leadership, the SEA would mark only the beginning of a new era, leading to adoption of euro and creation of a Union. As regards Monnet's regionalism, HI practitioners criticized it for having overestimated the strength of supranational institutions while underestimating the power of intergovernmental structures. According to Monnet's regionalism, all intergovernmental structures in Europe-building should be temporary and transitional, or, in sum, a prelude before the establishment of permanent integrated institutions. However, these intergovernmental structures often proved to be sufficiently powerful to absorb or weaken those already existent integrated organs. For example, the Comitology inside the Commission developed into a counter-balancing institution of the College itself in the 1960s. The deciding power was shifted from the Council to the summit in the aftermath of constitution of European Council. Both Monnet's and Gaullist regionalism neglected or underestimated the constraints imposed by the existent institutions. 


\section{A Synthesized Framework of Analysis for Asian Integration}

According to abovementioned analysis, power structure, degree of transnational elite cooperation, the spillover potential of the first sector integration, the normative appeal produced by the integration projects, and the institutional constraint all worked together to explain the rise and fall of different regionalism in Europe between 1945 and 1974 (Fig. 1). Accordingly, to evaluate the competing approaches to regional integration in Asia, it is necessary to study firstly power structures, the strategies preferred by important powers inside and outside of the region, and the probable compromises between them. Afterwards, it will be constructive to understand probable cooperation among elites in different countries of the region with the aim of analyzing whether or not such cooperation could develop into a transnational elite leadership, as neofunctionalists hoped. In parallel, it is useful to analyze the key sector integration that might constitute the original integration of regionalism and lead to later spillover effects. Fourthly, a comparison between institutional building and the future development of various projects would help measure their potential influence in the region. This comparison should include their regulatory, normative and cognitive institutional evolutions, with the assumption that the most advanced would prevail over the others as the mainstream integration strategy in Asia.

\section{Power Structure and Probable Compromises}

The US is still, without doubt, the dominant power in Asia in all fields. In economic terms, it is bigger than the combined GDP of Japan and China. In military terms, its defense budget is ten times as large as the PRC, and America maintains military bases in Okinawa, Korea, Japan and Guam. The Seventh Fleet is equipped with at least two aircraft carriers and dominates the Western Pacific. It maintains alliances with Japan, South Korea, the Philippines, Thailand, Australia and New Zealand, which collectively constitute the so-called Major Non-NATO Allies (MNNA) of the US in the Asia-Pacific. The dollar remains the de facto world and regional currency, with more than $70 \%$ of foreign reserves in the hands of regional exporting states being kept in dollars. More importantly, as Asia as a whole failed to start regionbuilding or transnational reconciliation-as Europe has done after WWII-the peace and stability in Asia has been dependent on US-led bilateral alliances and American hegemonic power in the region.

Compared to the US, the ASEAN as a whole, or any individual member state of the ASEAN, stands at the other extreme of the power spectrum. Indonesia, the

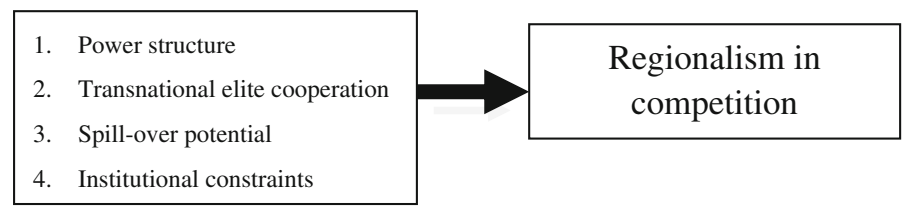

Fig. 1 A framework of analysis for regionalism in competition 
largest member, has a GDP of US $\$ 700 \mathrm{bn}$, which is just $5 \%$ of that of the US, onetenth of Japan or China. The ASEAN as a whole produces US $\$ 1,800$ bn a year, roughly equivalent to $26 \%$ of that of Japan or China. Political disturbance as well as ceaseless ethnic tensions or conflicts within several member states has further weakened the ASEAN. As for Japan, it was the leading engine in Asian economic development and has long enjoyed the status of American most privileged partner and most reliable ally in Asia. However, the economic stagnation in the past two decades, the fast aging society, and the unstable governments since resignation of Koizumi contributed to continual weakening of Japanese power in Asia. To be worse, American governments have never fully supported Japan-initiated integration projects, as is revealed clearly by its refusal to support the AMF initiative in 1997-1998. Neither Hatoyama's proposal nor Kuroda's initiative was convincing to American governments.

Accordingly, the PRC is perceived as the only country that might be capable and willing to challenge American power in the region. Although still trailing the US in all fields, China's rapidly expanding economy and rising political influence has begun to challenge American hegemony in Asia, even when this may run counter to the intentions of the PRC leadership. The rise of China has also made it clear that American influence over Asian integration could be fading fast. Considering the bitter history of trans-Atlantic integration, US seem to have to make a decision to treat Asian integration as either an opportunity or threat. If American projects for the Pacific cooperation are to be presented as countermeasures to brake, contain or mitigate Asian integration, the US will be bypassed as Asian regional development proceeds. Although the US remains dominant in all fields in Asia, America-led regionalism could be fading. Accordingly, as ASEAN is not strong enough to compete with neighboring powers, the future Asian integration is likely to be characterized by conflicts and competition either between China's and American regionalism, or between Japan's preferred ADB framework and China-concentric integration. A Sino-Japanese compromise might be likely if China continues to rise and Japan is firmly supported by the US on the issue of Asian integration.

\section{Cooperation of Transnational Elite as Leadership in Integration}

As regards cooperation of transnational elite, an American-led trans-Pacific regionalism seems capable of assembling a greater number of elite from various Asian nations than are other regionalism. America is still the most important destination of Asian elite seeking advanced studies abroad. These US-trained transnational elite were not only educated at American top universities, but could have worked and lived in the US for a period of time, meaning that they were quite familiar with American culture and often with each other, though they might have very limited knowledge about their Asian neighboring countries. Through their period of education in the US, elite are more or less socialized and 'Americanized' to the extent that they constituted a specific Asian community with linkages to their American counterparts. American NGOs, foundations or alumni societies helped reinforce and strengthen these linkages. This community has the potential to serve as the transnational elite that neofunctionalists hoped to see lead future integration. 
Compared to this US-educated community, Japan and ASEAN lag behind. Even when Japan has tried to recruit an equal number of international students from Asia, Japan-educated elite have not yet constituted leading and influential groups in their homelands. They are often limited to acting within specific fields, such as Japanese language or law, and unable to exercise a general influence in their societies. As for the ASEAN, exchanges between the elite of member states were very frequent to the extent that socialization did occur among them and constitute an elite community inside ASEAN. This socialization might be accelerated and enlarged in process of community-buildings under the new Charter. However, this community seemed to be limited inside ASEAN, which has not yet proved able to be enlarged to other Asian countries.

China surely does not enjoy the influence that the US has established among Asian elite. But communities of overseas Chinese and ethnically Chinese have the potential to harness the cooperation of transnational elite and take on leadership roles in driving integration. Chinese 'bamboo' networks based on family, regional communities, religious groups and even associations of martial artists have been established and are developing rapidly in Southeast Asia and North America. But these ethnically Chinese are in general business people, quarantined from the political power.

\section{Original Integration as Source of Future Spillover Effects}

All regionalism in Asia except Japan's approach and SCO began integration with the creation of free trade of industrial goods. As regards Japan, it based its regionalism upon the monetary cooperation in Asia. However, neither proposal establishing an AMF nor the initiative at creation of an Asian Community did present concrete roadmaps and indicate their future developments. Japan's project for the AMF in 1998 was proposed as an urgent solution to Asian financial crisis and no thought was taken regarding further cooperation or integration based upon that cooperation. Its initiative of Asian Community remained as an idea for discussion. All other regionalism proved to create some spillover effects to different degrees. The SCO began integration with cooperation on security issue, which was later developing into more general political cooperation and even initiation of a free trade zone. Concerning the pathfinder approach proposed by Australia and the US, it did constitute the original integration among selected APEC member countries. Trade facilitation measures and free movement of certain industrial goods led to the free movement of businesspersons and standardized certificates of origin, paving way to future development of TPP. Defined as high quality FTA, the TPP will not only create a free trade zone but constitute a community adhering to similar standards in all traderelated issues. As for the ASEAN plus, the early harvest program did achieve its target to facilitate lifting of trade obstacles in all fields, paving way to the free movement of goods since 2010. However, ASEAN Plus would seemingly stop at constitution of a free trade zone of goods without any intention or potential to develop into a more integration polity. Contrary to ASEAN Plus, the ASEAN-building itself seems to have made a great leap from its decision to establish a free trade zone and adoption of a charter with the aim to establish three communities in 2015. 
Institutional Buildings

Among institution-buildings of all regionalism, APEC prevailed in the regulatory sphere while ASEAN was deemed the champion in the cognitive field. The pathfinder initiatives of the APEC were now fruitful and TPP aimed to create a strictly regulated trade zone in the Pacific, while the ASEAN Charter has granted it a legal personality and all of the necessary symbols. But neither APEC nor ASEAN Charter established a strong normative pillar in its regionalism. APEC was initiated as a pure trade and economic program, in which subjects such as counter-terrorism and regional security were only recently injected owing to American insistence. ASEAN promoted non-proliferation and regional security since the end of Cold War, which, however, never constituted strong values and norms in its external action. China-preferred two circles of integration were also based upon shaky institutions. Though SCO has also developed complex institutions, its regulatory, normative and cognitive influences were nonetheless very weak. Its intergovernmental cooperation based upon consensual rule reduced its regulatory power, the non-democratic regimes of its member states mitigated its appealing values, and its implicit anti-Western nature as well as its heterogeneity could prevent it from developing its own identity. Nor did the ASEAN plus process create strong institutions as its institutional development was affiliated to and mitigated by ASEAN. In the end, none of these strategies have ever built up institutions strong enough to dominate Asian integration.

\section{Conclusion}

With reference of European integration between 1950 and 1974 and theoretical debate of integration theories, US-led trans-Pacific regionalism could continue to dominate Asian integration. Existing power structure in the region still favors the US, which also benefits from the cooperation of US-educated transnational elite. The pathfinder initiative operative within the APEC and the undergoing negotiation of TPP could be further developed and realize spillover effects in the long run. The Achillees' Heel of US-preferred regionalism is its institutional building as APEC was built up as a loosely cooperative group focusing on trade. As a result, it suffers lack of regulatory, normative and cognitive forces to constitute solid institutions. This institutional handicap resulted from skepticism and passivism of American approach to Asian regionalism. Based upon its own power in all fields and its bilateral alliances with Asian countries, American governments and their leaders have never worked out a long-term strategy on Asian integration. Therefore, in order to sustain its privileged status in Asian integration, the US must abandon its passivism and skepticism and adopt a new policy. It must work jointly with other Asian nations to consolidate the regulatory, normative and cognitive pillars of the APEC to the extent that its regulatory power is binding and efficient, its values and norms are appealing to Asian elite and people, and its cognitive pillar succeeds in establishing a strong identity in Asia. 
If the US refuse to engage directly in Asian integration as its trans-Pacific regionalism implies, the US could opt for the Japan-led ADB integration by offering support of its transnational elite community, and by exploiting the current power structure. However, the US and Japan will have to identify the ideal field in which to begin integration and on which to imagine an institutional framework equipped with regulatory, normative and cognitive powers. This is also the only chance for Japan to lead the Asian regionalism in the future.

The US could also opt for cooperation with the PRC in the latter's efforts to build up the ASEAN plus as regional integration. The ideal way for the US to penetrate this building process would be the creation of a larger framework in which to contain, reorient and support the China-led integration movement. This larger framework could contain Chinese military power and deter its resort to force in territorial conflicts as its power rises. It should also work to reorient Chinese internal and external actions. For example, the normative power of this larger framework should aim to facilitate and accelerate democratization in the PRC and its cognitive arm should aim to accelerate intra-Asian reconciliation. However, to adopt such a policy, the US also need to revise, redefine and even reorient its approach to Asian regionalism. If the US refuse to adapt itself to the fast evolving Asian regionalism, it could leave place to the PRC or ASEAN as China's economy is fast developing and its political influence is rapidly rising and ASEAN is accelerating construction of its communities.

As a result, PRC and ASEAN could enter into fierce competition once US is reluctant to adopt a more active and appropriate policy toward Asian regionalism. Nonetheless, the PRC would not replace US as the leading power in Asian regionalism in the near future though the ASEAN Plus could serve as a modest starting point for a potentially brilliant future. How to exploit this regional building for Chinese and all Asian countries is a serious challenge to the Chinese leaders and elite. Taking into account the current power structure, which still favors the US, and the very primitive institutions of the ASEAN plus arrangement, Chinese leaders have opted to maintain a low profile for the time being. However, repeated Chinese proposals that put into doubt the status of the US dollar as the world's reserve currency, a more and more active foreign policy in Africa, and accelerated contracting for access to energy resources seem to constitute a prelude to the revision and even reorientation of Chinese external action, including China's approach to Asian regionalism. But, even if power structures continue to evolve in favor of China, the PRC will nonetheless fail to mobilize the 'bamboo network' of oversea Chinese and those pro-Chinese elite owing to its lack of appealing values and norms. In parallel with further engagement in Asian integration, the PRC cannot but reform its internal politics to constitute a polity based upon democracy, the rule of law and protection of human rights.

So must the ASEAN as well. Surely it must accelerate its economic development in order to narrow the power gap between itself and those outside giants, and build up its planned communities with the aim of strengthening its institutional power and transnational socialization. ASEAN countries must, at the same time, pursue for and consolidate the democracy and ASEAN as a whole must promote democracy as its common paramount value to strengthen its normative appealing. Inclusion of 
articles on protection of human rights in the Charter might indicate the new beginning of a long journey. States and people would like to make trade with each other but no transnational elite will work together to promote integration with those non-democratic states or polities. Integration initiated by those non-democratic countries will be totally dependent upon interests and power, without any normative and cognitive influences. Accordingly, even if power structure is evolving not in favor of the US, its approach to Asian regionalism will continue to prevail and be unchallenged as long as the PRC and ASEAN as whole are far from a democracy. "History has taught us not to underestimate the power of utopia. Too often in the past it has proved difficult to foresee a systemic change that would turn a utopia vision into a political project." (Stein 2001)

\section{References}

Bloes R (1970) Le plan Fouchet et le problème de l'Europe politique, Bruges (Belgique), Collège d'Europe

Boisseau du Rocher S (2006) ASEAN and Northeast Asia: stakes and implications for the European Union-ASEAN partnership. Asia Eur J 4(2):229-249

Chia SY, Sussangkarn C (2006) The economic rise of China: challenges and opportunities for ASEAN. Asian Econ Policy Rev 1:119

Du L (2011) Comments on US Strategy for promoting trans-Pacific partnership. Working Paper at CIIS (China Institute of International Studies). http://www.ciis.org.cn/english/2011-08/03/content_ 4380581.htm. Retrieved 22 Sept 2011

Duke S (2000) The elusive quest for European security: from EDC to CFSP. Palgrave, New York

Dumoulin M (2000) La Communauté Européenne de Défense, Leçons pour Demain? Bruxelles; New York: P.I.E.: P. Lang

Economy E (2005) China's rise in Southeast Asia: implications for Japan and the United States. Jpn Focus J 414. http://www.japanfocus.org/category.asp?id=22. Retrieved 27 December 2005

Elek A (1998) Open regionalism going global: APEC and the new transatlantic economic partnership. Pacific Economic Paper No. 286:1-32

Endo K (2002) The security foundations of economic integration: a comparison between East Asia and Western Europe. In: Dent CM, Huang DWF (eds) Northeast Asian regionalism: learning from the European Union. RoutledgeCurzon, London, pp 226-242

Garrett G, Tsebelis G (1996) An institutional critique of intergovernmentalism. Int Organ 50(2):269-299

George S (ed) (1992) Britain and the European community: the politics of semi-detachment. Clarendon Press, Oxford

Gerbet P (1983) La construction de l'Europe. Imprimerie nationale, Paris

Green M (2002) Japan's reluctant realism. Palgrave, Basingstoke

Green MJ (2007) American quiet victories in Asia, Washington Post, p A21

Haas EB (1964) Beyond the Nation-State: functionalism and international organization. Stanford University Press, Stanford

Haas EB (1975) The obsolescence of regional integration theory. Institute of International Studies, Berkley

Hall PA, Taylor RCR (1996) Political science and the three new institutionalisms. Political Stud 44(5):936-957

Harryvan AG, van der Harst J (eds) (1997) W Churchill's speech at Zurich University, Documents on European Union. Macmillan Press, London

Hass EB (1958) The uniting of Europe: political, social and economic forces 1950-1957. Stanford University Press, Stanford

Hoffmann S (1982) Reflection on the Nation-State in Western Europe today. J Common Market Stud 21(1-2):21-38

Howarth DJ (2001) The French road to European monetary union. Palgrave, New York 
Kohlscheen E, Taylor MP (2008) International liquidity swaps: is the Chiang Mai initiative pooling reserves efficiently? Int J Finance Econ 13:323-332

Kohnstamm M (1984) Interview de Max Kohnstamm par Roberto Ducci et Mme Maria Grawia Melchionni le 27 septembre 1984, Série d'histoire. Archives de la Fondation Jean Monnet pour l'Europe, Lausanne

Laffan B (2001) The European Union policy: a union of regulative, normative and cognitive pillars. J Eur Public Policy 8(5):711-713

Lagrange M (1980) Entretien avec Maurice Lagrange par Antoine Marès, 23/09/1980, Fondation Jean Monnet pour l'Europe

Leibfriend S, Pierson P (1997) Social policy. In: Wallace Helen, Wallace William (eds) Policy-Making in the European Union. Oxford University Press, Oxford, pp 267-292

Men J (2007) The construction of the China-ASEAN free trade area: a study of China's active involvement, Global Soc 21(2):249-268

Miller JH (2004) The reluctant Asianist: Japan and Asia. Asian Aff Am Rev 31(2):69-85

Moravcsik A (1991) Negotiating the single European act: national interests and governmental statecraft in the European Community. Int Organ 45(1):19-56

Moravcsik A (1993) Preferences and powers in the European Community: a liberal intergovernmentalist approach. J Common Market Stud 31(4):473-524

Moravcsik A (1995) Liberal intergovernmentalism and integration: a rejoinder. J Common Market Stud 33(4):611-628

Paul Taylor, Groom AJ (eds) (1983) Functionalism: theory and practice in international relations. Columbia University Press, New York

Pierson P (1996) The path to European integration: a historical institutional analysis. Comp Political Stud 29(2):123-163

Richard R, Haerpfer Ch (1995) Democracy and enlarging the European Union eastwards. J Common Market Stud 33(3):427-450

Soutou G (1996) L'alliance incertaine. Fayard, Paris

Stein E (2001) International integration and democracy: no love at first sight. Am J Int Law 95:534 (489-534)

Su H (2007) Politics of differentiation: enhanced cooperation in the EU and pathfinder in APEC. Asia Eur J 5:51-66

Su H (2009) Jean Monnet's great design for Europe and its criticism. J Eur Integration Hist 15:29-45

Tranholm-Mikkelsen J (1990) Neo-functionalism: obstinate or obsolete? A reappraisal in the light of the new dynamism of the EC. Millennium J Int Stud 20(1):1-22

Webber D (2001) Two funerals and a wedding? The ups and downs of regionalism in East Asia and AsiaPacific after the Asian crisis. Pacific Rev 14(3):339-372

Park YC (2002) Can East Asia emulate European economic integration? Paper presented at the PECC finance forum conference at Honolulu, 11-13 August 2002 